\title{
ИНТЕРКУЛТУРНО ОБРАЗОВАЊЕ И УЧЕЊЕ СТРАНИХ ЈЕЗИКА У ПРЕДШКОЛСКОМ УЗРАСТУ
}

Интеркултурно образовање данас чини саставни део наставе страних језика, али се и даље полемише о прикладности и могућности имплементације овог аспекта у процес учења страних језика у предшколском узрасту. Опсервацијом часова страног језика у неколико предшколских установа у Београду, установљено је да се код деце већ у том добу могу јавити предрасуде и негативни ставови према другим културама, као и да наставници врло често немају свест о значају развоја интеркултурне компетенције код ученика и да пропуштају прилике за рад на том плану, што је првенствено последица њихове неадекватне обучености.

Кључне речи: интеркултурно образовање, страни језик, предшколски узраст, толеранција, стручно образовање

Савремено доба је доба комуникације и глобализације, а кључне елементе за успех у тим доменима чини познавање језика и саговорника. Значај учења страних језика се не доводи више у питање, као што је већ опште прихваћена и чињеница да интеркултурна димензија чини неизоставан циљ и сврху наставе језика, почевши од најранијег узраста (Вучо 2010: 1). Бајрам и др. (2002: 7) сматра интеркултурну димензију природним продужетком савремене наставе језика усмерене на развој комуникативне језичке способности. Учење страног језика нераскидиво је повезано са упознавањем културе народа који се тим језиком служи, јер се у њему огледају све особености које ту културу чине таквом каква јесте (Вујовић 2006: 63).

1 jvisacki@gmail.com 
Стицање комуникативне компетенције главни је циљ учења језика данас. Ученика треба оспособити за разговор на страном језику, без инсистирања на граматичкој апсолутној тачности. Низак ниво језичког знања представља свакако озбиљну препреку за комуникативну компетенцију, али висок ниво језичке компетенције не гарантује успешну комуникацију (Вујовић 2006: 64); познавање језика може да обезбеди међусобно споразумевање, али не и нужно међусобно разумевање. Комуникација на страном језику подразумева дијалог који се одвија на више нивоа истовремено, односно, не размењује се само лексички садржај, већ и екстралингвистички контекст у коме тај језички садржај постоји (Живковић 2013: 5). Интеркултурна компетенција употпуњује дакле појам комуникативне компетенције и представља вештину стварне интеракције са људима из различитих култура (Бајрам и др. 2004: 297). Како наводи Дурбаба (2016: 76), основни задатак интеркултурне наставе треба да буде стицање знања, вештина и навика у тумачењу и разумевању елемената стране културе.

Интегрисањем интеркултурне компоненте у курикулум наставе језика и њеним спровођењем помаже се упознавање и прихватање другог и његовог система вредности. Образовање није и не треба да буде само израз окружења и друштва у којем се одвија, већ и само треба да утиче на развој тог окружења (Гошовић и др. 2007: 13). Самим тим, ни увођење интеркултурног образовања не треба одлагати, већ га треба започети у што ранијем узрасту. Премда је интеркултурну димензију лакше имплементирати у настави са старијим ученицима јер им је јасна њена сврха (Хлопек 2008: 18), учење страног језика је прилика да се и код мале деце позитивно утиче на развој личности; упознавањем другачијих начина живота деца се уче да отворено и толерантно прихватају и поштују другог. И док поједини аутори верују да је за интеркултурну сензибилизацију потребна когнитивна зрелост коју деца још увек немају (Дурбаба 2016: 288), за Поршеа (Порше и др. 1998: 82) интеркултурни аспект је један од најзначајнијих аргумената у корист раног учења страних језика, јер помаже - како 
он наводи - у борби против етноцентризма, социоцентризма и егоцентризма. Наиме, деца се кроз наставу језика упознају са чињеницом да на свету постоје различита мишљења и другачија виђења, указују им се осим тога разлике и сличности које се јављају у оквиру једне исте културе, а помаже им се и у изградњи сопственог гледишта, као и у спознаји да оно није јединствено и да није ни мање ни више вредно од осталих (Бајрам 2008: 37). Интеркултурним образовањем грађана од чијег развоја зависи будућност земље, хвата се правац ка унапређењу друштва и ка стварању једне толерантније и сигурније средине.

У Србији је од школске 2003/2004. године уведено обавезно учење језика почевши од првог разреда основне школе. Ипак, и у већини приватних вртића, као и у појединим државним, страни језик чини саставни део предшколског програма, те се велики број деце са овом наставом сусреће још пре поласка у школу. Ако се прихвати став да интеркултурно образовање треба интегрисати у наставу страног језика на сваком узрасту, потребно је одредити начин на који се то спроводи када је реч о предшколцима, а поставља се уједно и питање колико је то примењиво у оквиру програма који, у Србији, за поменути узраст још увек није адекватно законски регулисан, па се од установе до установе разликује по интензитету, фреквентности и дужини часова. Намеће се и питање потребе за поменутом интеркултурном наставом у земљи као што је Србија, посебно ако се узме у обзир већ наведена чињеница да учење језика није доступно свој деци предшколског узраста већ остаје привилегија имућнијих појединаца.

\section{Функције интеркултурног образовања}

Сваки сусрет са културом неке друге земље заправо је улаз у један нов и узбудљив свет. Иако би у њега требало ући са отвореним и заинтересованим ставом, због постојећих стереотипа и предрасуда, или можда из неког страха од непознатог, то често није случај. Стереотипи, било позитивни или негативни, 
могу бити засновани на истини, али свакако се јављају када недостаје знања, а афективни односи ојачају. Предрасуде се дефинишу као скуп осећања, судова и индивидуалних ставова који изазивају или подстичу дискриминацију, и то најчешће према културама са чијим се носиоцима у прошлости или у садашњости одржавају непријатељски односи (Вујовић 2006: 68-72). Поједини аутори су се бавили проучавањем оваквих појава. Тако је Барна (1998: 337-342) издвојио шест препрека, тзв. камена спотицања који се јављају при интеркултурној комуникацији: претпоставка о сличностима, језичке разлике, погрешне интерпретације невербалних порука, предрасуде и стереотипи, потреба за вредновањем и анксиозност. Бенет (1993 у Живковић 2013: 3) је са своје стране предложио развојни модел интеркултурне осетљивости у којем описује стадијуме кроз које појединци пролазе када се сретну са другим културама, а који иде од крајњег етноцентризма и стадијума порицања постојања разлика до етнорелативизма и уочавања, односно, прихватања разлика.

Да би био способан да разуме различитост, човек мора првенствено да упозна себе, да преиспита своје дубоко укорењене ставове и уверења, да развије способност гледања из перспективе других. Таква способност се учи и стиче, она се не развија интуитивно (Ачаји 2011: 3). Интеркултурно образовање омогућава управо стицање интеркултурне компетентности која подразумева најпре свест о себи као комплексном културном бићу, затим свест о утицају који култура врши на мишљење и на понашање сваког појединца, способност да се сви ангажују у истраживање прећутних претпоставки које директно утичу на понашање и, најзад, отвореност ка сагледавању различитих гледишта, начина мишљења и ка решавању проблема (Гошовић и др. 2007: 12). Упознавањем сопствене културе и утврђивањем сопственог система вредности кроз поређење са другим културама, ученик постаје осетљив на идеју да су људи природно развијали различите начине живота и обичаје, и да је разноликост људског живота заправо велико богатство (Лукач Зоранић и Ивановић 2014: 1084). То га чини способним да разуме другог и прихвати постојање различитог. 


\section{Потреба за интеркултурним образовањем у Србији}

Сукоби који су се десили на територији бивше Југославије сведоче о томе да је то био простор на којем су живеле друштвене групе различитих вера и националности, које за време своје коегзистенције нису успеле да остваре међусобну интеракцију, чак су напротив продубиле међуверску и међунационалну нетрпељивост. До нагомилавања тензија и избијања рата дошло је и због дугогодишњег систематског потискивања и негирања културних разлика (Лукач Зоранић и Ивановић 2014: 1088). Ова болна искуства, као и сиромаштво, лоша економска ситуацја и изразито слаба мобилност становништва ${ }^{2}$, довели су до етничког анимозитета и нетолеранције међу људима у Србији. Проблем прави и недовољно и/или искривљено познавање историје и културе сопственог народа (Гошовић и др. 2007: 33). Разна истраживања спроведена 2004. и 2008. године, пре свега на младима, показала су високу стопу ксенофобије, неспремности за прихватање и разумевање разлика других култура, другачијих вредности, као и постојање велике социјалне дистанце међу студентима различитих етничких група (Гошовић и др. 2007: 33, Вучо 2008: 4, Живковић 2013: 1).

Интеркултурно образовање један је од кључних елемената у поступку проналажења излаза из овакве ситуације. У његово спровођење треба укључити све сегменте друштва, од различитих државних установа и институција, па све до медија. Школа, почевши од предшколског узраста до универзитетског нивоа, остаје ипак најподобнија средина за развој интеркултурне компетентности. У Србији, иако постоје правне претпоставке на које се увођење интеркултурног образовања може ослонити - као на пример Устав Републике Србије, Закон о основама система образовања и васпитања, Закон о забрани дискриминације и бројни други документи, оно и даље не чини интегрални део општег школског програма. Није постављена стратегија која би се односила не интеркултурне вредности и принципе у образо-

2 Истраживање спроведено у Србији 2004. године показало је да чак 70\% студената никада није било у иностранству (Живковић 2013: 8). 
вању, због чега се оно у овом тренутку своди на обезбеђивање образовања на матерњем језику за националне мањине, а повремено се у школску праксу укључују и поједини садржаји или теме различитих мањинских култура. Учење о светским културама, религијама и традицији убачено је у курикулум као део одређених школских предмета. Овим се, међутим, не обезбеђује стицање интеркултурне компетенције, као ни зближавање различитих етничких група; образовни систем на овај начин само толерише паралелно егзистирање неколико култура и задржава се дакле на мултикултурном нивоу (Аксентијевић 2009: 10-12).

\section{Одлике интеркултурне наставе}

У оквиру основног и вишег образовања, увођење ученика у страну културу треба вршити систематски, константно и синхронијски, са што мање понирања у историју, поготово у млађим разредима (Вујовић 2006: 67). Препоручује се спровођење овог процеса у три фазе од којих прву треба да чини суочавање ученика са вредностима сопствене културе и евентуално других блиских култура, друга подразумева упознавање са специфичностима народа који говоре језик који се учи, а у оквиру треће се обухватају културе широм света (Хлопек 2008: 12). Анри Бес (1984 у Вујовић 2006: 72) наглашава да сусрет са донекле необичним подацима о страном језику и култури може подстаћи и развити будност и радозналост оних који уче. С друге стране, не треба избегавати ни употребу стереотипа у настави јер, иако се сматрају извором предрасуда, они чине део предзнања студената, те могу послужити као ослонац и полазна тачка у приближавању новог културног система. У исто време, они наводе ученике на размишљање и о сопственом свету, о сопственој култури која је те стереотипе формирала, што им омогућује да сами себе боље упознају (Вучо 2010: 2). Само променом представа које ученици имају о свом етничком идентитету може се постићи промена у начину на који виде 
друге. Да би до ових промена дошло, ученике треба суочити са објективним виђењем које странци имају о њима (Вујовић 2006: 69).

Задатак наставника није, дакле, да уклања стереотипе како би доказао да међу људима нема разлика, као што није ни да приморава ученике да се са свим разликама и обичајима сложе (Хлопек 2008: 18); наставник треба ученицима да помогне да уоче постојање разноликости, да ту чињеницу прихвате и да схвате да су циљеви процеса размене који се одвија између њихове матерње и стране културе уклањање препрека, реципрочност и солидарност (Вујовић 2006: 72). Важно је да им помогне да интеракцију с људима других култура схвате као обогаћујуће искуство (Дурбаба 2016: 299).

\section{Учење страних језика и интеркултурно образовање у предшколском узрасту у Србији}

Поједине анкете спроведене 2005. и 2007. године (Вучо 2008: 3-5), које су обухватале студенте и средњошколце, показују да у Србији постоји јасан анимозитет и према страном језику уопште. Учење страних језика доживљава се као „опасност“ која прети српском језику и култури. Да се потешкоће у прихватању савремених идеја у вези са учењем језика могу јавити и на нивоу политичких и научних ауторитета видело се у време реформе образовног система Србије у периоду од 2001. до 2004. године када је страни језик, уведен од првог разреда основне школе, преиначен из обавезног у факултативни. Непостојање јасне државне стратегије у језичкој политици, као и необавештеност о бројним предностима раног учења језика, допринели су прављењу овог корака уназад у односу на европске и светске тенденције у тој области (Вучо 2006: 45). Страни језик је касније поново сврстан у обавезне предмете, а школске 2005/2006. године додат је чак и други, такође обавезан језик, и то од првог па од петог разреда основног образовања. 
Значај увођења интеркултурног образовања у узрасту када се формирају својства, ставови и склоности које су важне за даље уобличавање личности (Каменов 1999: 33), један је од главних аргумената у корист учења страног језика већ у предшколском добу. У Србији, нажалост, у овом моменту страни језик још увек није саставни део редовног предшколског програма, те због мањка финансијских средстава и ограничавајуће законске регулативе ${ }^{3}$, учење језика се углавном не спроводи у државним вртићима већ најчешће остаје привилегија приватних установа.

Чињеница је да се код деце предшколског узраста често јавља склоност да вредности сопствене средине отворено прихватају као најбоље и једине праве, и да постоји могућност да се овакав став са одрастањем не промени уколико им се од најранијег детињства не укаже на то да су културне и вредносне разлике израз богатства и пожељне разноврсности (Вујовић 2007: 427). Програм страног језика заправо је идеална прилика за прихватање и привикавање на постојање других култура и различитих схватања, као и за развијање толеранције и емпатије. Пракса показује да деца, баш као и када се ради о учењу језика, са већом лакоћом од одраслих усвајају нове културне обрасце. Наравно, садржаји и приступ интеркултурном образовању морају бити прилагођени узрасту (Гошовић и др. 2007: 23).

У предшколском узрасту, интеркултурно образовање и настава језика подразумевају пре свега сензитивизацију на стране језике и на постојање међујезичке и међукултурне комуникације. Ученике треба упознати са идејом о постојању других језика који се користе као средства комуникације и са елементима културе која се разликује од полазне. Важно је

3 Правилник о врстама, начину остваривања и финансирања посебних, специјализованих програма и других облика рада и услуга које остварује предшколска установа (“Службени гласник РС “, број 26 /13) дозвољава учешће родитељау обезбеђивањунеопходних финансијских средстава за остваривање тзв. специјализованих програма у које спада и страни језик, само уколико се програми одржавају ван радног времена вртића, што у већини случајева родитељима временски не одговара. 
да им се поред основа комуникативне компетенције, развије и позитивно осећање према језику који се учи (Вучо 2010: 5). Конфронтација и поређење компонената сопственог и страног омогућава, као што је већ речено, да се кроз представљање другачијих обичаја деца упознају и са елементима националне културе, што је управо један од основних циљева предшколског образовања. Откривање особина по којима се разликује или је слично другима, детету омогућава да спозна и прихвати и самог себе (Каменов 1999: 243).

Деца се развијају најпре под утицајем своје породице и свог окружења, па већ у раном узрасту могу имати предрасуде. Међутим, с обзиром на чињеницу да у предшколском узрасту процес развоја личности још није завршен, вртић као посебно окружење омогућава да се разноликости ставе у први план, а васпитачима и наставницима пружа прилику да непосредно учествују у формирању темеља будућег позитивног односа према другима. Доживљај, односно слика света према којој се тумаче каснији доживљаји и искуства формира се у детињству и делује из најдубљих слојева људске личности (Каменов 1999: 31).

Рад на развоју интеркултурне компетенције код ученика предшколског узраста захтева од наставника да утиче пре свега на себе и на своје ставове, да их мења ако је потребно, јер он није више само обавештени познавалац одређене културе, већ онај који развија критички став других. Не треба да фаворизује ни циљну ни полазну културу (Вучо 2013: 2), и од њега се очекује да омогући атмосферу у којој се поштују и прихватају разлике. Наставник треба, дакле, пре свега да се ослободи сопствених предрасуда јер под њиховим утицајем неће бити у могућности да пренесе на своје ученике отворен став према другима.

\section{Интеркултурност у пракси}

Примери из праксе наведени у даљем тексту забележени су приликом истраживања спроведеног током јесени и зиме 2015. године у Београду, за потребе докторске тезе насловљене 
Курикуларни оквир за наставу страних језика у предшколском узрасту у Србији. Истраживање је било емпиријско-теоријског карактера и спроведено је у 14 различитих предшколских установа у којима се учи један или више страних језика. Коришћена је дескриптивна метода, а од техника примењене су, између осталог, анкетирање, скалирање, интервјуисање и опсервација.

Анкетни упитник, састављен као комбинација анкете и дескриптивне скале, био је дат наставницима ради прикупљања података о различитим аспектима рада, међу којима је и мера у којој укључују интеркултурно образовање у наставу. Интервју је урађен у циљу продубљивања сазнања о ставу наставника према укључивању интеркултурног аспекта у наставу, а додатни подаци о самом процесу спровођења интеркултурног образовања забележени су опсервацијом неколико узастопних часова у оквиру сваке групе.

Међу циљевима овог истраживања било је спровођење критичке анализе језичких и методолошких аспеката уочених током опсервације наставе и њихово поређење са одговарајућим теоријским начелима. Једна од хипотеза на којима се базирао рад гласила је да настава страних језика у раном узрасту није потпуно афирмативна у односу на савремена начела плурилингвизма и мултикултурности у образовној политици Европе.

Квантитативном анализом и унакрсном квалитативном анализом резултата прикупљених поменутим инструментима, добијена је јаснија слика у вези са постављеним хипотезама. Наиме, потврђено је да се у већини програма на којима предшколске установе базирају свој рад не поштују сва савремена начела плурилингвизма и плурикултурности. Примери из праксе, као и одговори дати у упитнику на тему примене интеркултурног аспекта у раду са децом, потврдили су да је учење језика идеална прилика за развој интеркултурне компетенције, као и да се негативни ставови могу осетити већ у тако раном узрасту, али да се на основу реакција наставника може, нажалост, закључити да је свест о потреби за интеркултурним образовањем у Србији прилично неразвијена. 
Пример 1: у једној од посматраних приватних предшколских установа, деци која похађају припремни предшколски програм омогућено је учење два страна језика. Други језик је француски и одвија се једном недељно у трајању од 45 минута. Наставница је филолог по струци, а француски јој је био изборни језик на основним студијама. По питању стручног усавршавања, на језичком плану поменута наставница нема додатне обуке, док се на педагошко-методолошком плану у малој мери усавршавала посредством тзв. webinara. На једном од посматраних часова ове групе, деца су обрађивала тему ноћи вештица и учила песмицу насловљену Halloween, halloween. У току певања, једна девојчица се обратила наставници и напоменула јој да су њој родитељи забранили да слуша и пева ову песму. На питање наставнице који је разлог за то, дете је одговорило да јој је мајка рекла да је то „песма о празнику који су измислили неки зли људи“, што се, по мишљењу наставнице, вероватно односило на амерички народ с обзиром на то да је ноћ вештица празник који се слави у Сједињеним Америчким Државама и који се последњих десетак година шири и ван њихове културе услед интеркултурних преливања. На основу става и гестикулације девојчице, могло се закључити да ни њој самој није било јасно зашто јој је то забрањено и шта је у чину певања и слушања поменуте песме заправо лоше. Нажалост, наставница није искористила прилику да и њој, као и осталој деци објасни порекло овог празника и да на начин који је адекватан за њихов узраст, укаже на проблем предрасуда и генерализације људи. Напротив, она је обећала да песму неће више пуштати и почела да правда рад на часовима објашњавајући да не раде ништа лоше, без даљег улажења у ову тему.

Пример 2: у другом београдском вртићу, деци је омогућено да два пута недељно уче енглески језик. Часови трају по 45 минута. Наставница је филолог по струци, тачније професор енглеског језика и књижевности, без додатног стручног усавршавања. У току једног од посматраних часова, деца су понављала научену лексику - и у овом случају - на тему ноћи вештица. Један дечак похвалио се да је „био у Америци где је за 
halloween видео пуно украшених лубеница“. Наставница није одреаговала на његов коментар, те је он наставио да понавља исту реченицу. Не желећи да настави овај разговор и у намери да га ућутка, наставница се обратила детету питањем „јел?“, не покушавајући да га исправи нити да објасни да то нису биле лубенице већ бундеве. По нашем мишљењу, она је пропустила прилику да искористи чињеницу дететовог путовања у државу која је далеко и коју већина остале деце можда није и неће имати прилику да посети и да уз афирмативни став укаже на одређене аспекте везане за друге културе.

Пример 3: у трећем вртићу, деца такође имају могућност да уче енглески језик два пута недељно по 45 минута. И у овом случају, наставница је професор енглеског језика и књижевности, а додатно се усавршавала кроз семинаре усмерене на учење кроз игру, покрет и друге деци прилагођене активности. У току једног од посматраних часова у овој установи, на помињање речи english, једна девојчица изјавила је како зна да „енглези морају да искористе нека два слова када желе да напишу глас ш“. Наставница је потврдила њене речи, наводећи да се ради о словима с и х, али је у шаљивом тону додала негативан коментар о „глупавим“ енглезима којима су потребна два слова за глас ш, за разлику од „паметнијих“ говорника српског језика којима је довољно само једно. Дакле, у ситуацији када је требало да направи паралелу између свог и другог народа, наставница је извршила поређење уз негативну конотацију на рачун другог. Иако се можда ради о „безазленом запажању“, после континуираног излагања оваквим опаскама, код деце може доћи до развијања негативног става и потребе за ниподаштавањем различитих култура. Циљ интеркултурног образовања је управо супротан.

Пример 4: у четвртој предшколској установи која је обухваћена наведеним истраживањем, деца уче енглески језик свакога дана по сат времена. Наставу држи професор енглеског језика и књижевности, без додатног стручног усавршавања. На једном од посматраних часова, наставница је задала деци вежбу у радној свесци, где је требало да пронађу и заокруже два иста лица међу бројним понуђеним цртежима. Док су радила овај 
задатак, деца су понављала заједно са наставницом научену лексику везану за делове лица. На поменутим цртежима била су приказана лица деце различитих раса. Као што је случај са већином савременог дидактичког материјала, и ова радна свеска иако је намењена тек предшколском узрасту обилује интеркултурним аспектима попут поменутог расног диференцирања. Овакве илустрације могу бити добар повод за разговор на тему различитости, али у описаном случају наставница се на то није осврнула и пропустила је погодну прилику.

Пример 5: у оквиру наведеног истраживања на тему учења страног језика у предшколским установама, наставницима језика дато је да попуне упитник у којем је једно од постављених питања било везано за примену интеркултурног аспекта у раду са децом. Понуђена је скала са цифрама од 1 до 5 за одређивање степена примене, са јединицом као најнижим, а петицом као највишим нивоом. Од 17 испитаника, само је четворо заокружило вредност већу од 3, а чак више од пола њих тражило је да се појасни ово питање и да се дефинише појам интеркултурности. Неопходност посебног обучавања наставног кадра најпре у циљу освешћивања о потреби за интеркултурном наставом, осим описаних ситуација потврђује и чињеница да је један од наведених примера дат са часа наставнице која је интензитет примене поменутог аспекта у свом раду оценила петицом.

\section{Закључак}

Како теоријске поставке, тако и наставна пракса потврђују да наставу страног језика не треба раздвајати од интеркултурног образовања. Наиме, учење језика с једне стране представља идеалан контекст за развој интеркултурне компетенције, а са друге, њено стицање у оквиру наставе базиране на комуникативном приступу сматра се циљем и сврхом учења језика. Ученицима данас више нису довољна само знања о језику, већ им је неопходна и вештина која помаже у остваривању интеракције са говорницима тог језика. 
Може се рећи да интеркултурно образовање има заправо две функције: прво да пружи ученицима знања о вредностима, обичајима и другим аспектима које деле припадници једног народа, како би се избегли евентуални неспоразуми у комуникацији, а друго да развије осећај толеранције, разумевања и поштовања различитости. Равноправним приступом комуникацији, што значи подједнаком свешћу о сопственом идентитету, као и о идентитету саговорника, омогућава се заправо тај отворен и позитиван став према другом.

Опште је познато да је предшколски узраст период интензивног развоја личности, подложног разним утицајима, што га чини идеалним тренутком за сусрет са другим језицима и различитим култура и за усађивање правих вредности. Учење страног језика у раном узрасту треба дакле да омогући формирање квалитетног темеља за даљу надградњу интеркултурне вештине.

Описане ситуације у којима се наставницима страног језика у неколико београдских вртића указала прилика да децу упознају са елементима друге културе или да исправе неке њихове предрасуде, показују да наставни кадар нема увек свест о потреби за развијањем интеркултурне вештине и да поменуте прилике углавном пропушта. Нестручност наставника на овом плану је, пре свега, последица њихове недовољне обучености. Обука је неопходна првенствено у циљу едуковања наставника о предностима развоја интеркултурне компетенције код деце која још нису кренула у школу, као и зарад превазилажења њихових сопствених предрасуда и стереотипа. Нажалост, у Србији, стручно образовање наставника страног језика у предшколском узрасту није законски прописан, а ни понуда неопходних програма за њихово стручно усавршавање није адекватна, те се јављају поменути пропусти.

Из примера се уједно може закључити да основ за интеркултурну наставу, поред дидактичких материјала и самог страног језика као неисцрпног извора различитих културних образаца, пружају и коментари, ставови и запажања деце. Овакав корак у развоју образовања не захтева, дакле, превелика 
улагања, а утицај на унапређење друштва може бити значајан; нажалост, узимајући у обзир чињеницу да ни сам програм страног језика у овом моменту није на располагању свим предшколцима у Србији, за усмеравање националне језичке и образовне политике у овом правцу биће потребно још времена и великог труда.

\section{ЛИТЕРАТУРА}

Ачаји 2011: Ačaji, M. (2011). Multikulturalno i interkulturalno obrazovanje: razvoj interkulturalne osetljivosti. Preuzeto 08. oktobra 2015., sa http://njnjnj.helsinki.org.rs/serbian/index_s.html.

Аксентијевић 2009: Aksentijević, Z. (prir.) (2009). Ne prolazi ulicom bez traga: ka interkulturalnosti. Beograd: Grupa 484. Preuzeto 26. oktobra 2015. godine, sa http://www.grupa484.org.rs/sites/default/files/ne-prolazi-ulicom.pdf.

Барна 1998: Barna, L. M. (1998). Stumbling Blocks in Intercultural Communication. In: Bennett, M. J. (ed.). Basic Concepts of Intercultural Communication: Selected Readings. Boston: Intercultural Press.

Бајрам и др. 2002: Byram, M., Gribkova, B., \& Starkey, H. (2002). Developing the Intercultural Dimension in Language Teaching: A Practical Introduction for Teachers. Strasbourg: Language Policy Division.

Бајрам и др. 2004: Byram, M., Adelheid, H. (ed.) (2004). Routledge Encyclopedia of Language Teaching and Learning. London, New York: Routledge.

Бајрам 2008: Byram, М. (2008). From Foreign Language Education to Education for Intercultural Citizenship: Essays and Reflections. Languages for Intercultural Communication and Education 17. (Proveriti kako kad je serija) Clevedon, Buffalo, Toronto: Multilingual Matters.

Вујовић 2006: Vujović, A. (2006). Jezik, kultura i komunikacija. U: Vujović, A. (ured.) (2006). Inovacije u nastavi: časopis za Savremenu nastavu, vol.19 (str. 63-74). Beograd: Učiteljski fakultet.

Вујовић 2007: Vujović, A. (2007). Nastava stranih jezika na učiteljskom fakultetu u Beogradu. U: Savremene tendencije u nastavi jezika i književnosti. Zbornik radova. Beograd: Filološki fakultet.

Вучо 2006: Vučo, J. (2006). U potrazi za sopstvenim modelom dvojezične nastave. U: Vujović, A. (ured.) (2006). Inovacije u nastavi: časopis za 
Savremenu nastavu, vol.19 (str. 41-54). Beograd: Učiteljski fakultet. Вучо 2008: Vučo, J. (2008). Srpski među ostalim jezicima. Zbornik radova sa međunarodnog naučnog skupa Srpski jezik u kontekstu, (str. 4553). Kragujevac: Filium.

Вучо 2010: Vučo, J. (2010). Interkulturalnost kao okvir i kontekst komunikativne nastave stranih jezika u ranom uzrastu. U: Radovanović, I. (2010). Inovacije u nastavi: časopis za Savremenu nastavu, vol.23 (str. 53-61). Beograd: Učiteljski fakultet.

Вучо 2013: Vučo, J. (2013). 0 nekim specifičnostima interkulturne razmene u savremenoj nastavi stranih jezika. U: Gudurić, S., \& Stefanović, M. (ured.) (2013). Jezici i kulture u vremenu i prostoru, II/1, str. 273379. Novi Sad: Filozofski fakultet.

Гошовић и др. 2007: Gošović, R., Mrše, S., Jerotijević, M., Petrović, D., \& Tomić, V. (2007). Interkulturalno obrazovanje. U: Vodič za unapređenje interkulturalnog obrazovanja. Beograd: Fond za otvoreno društvo. Preuzeto 05. oktobra 2015., sa http://www.pefja.kg.ac.rs/ preuzimanje/Materijali_za_nastavu/Nastava\%202011-12/Interkulturalno\%20obrazovanje/vodic.pdf.

Дурбаба 2016: Durbaba, 0. (2016). Kultura i nastava stranih jezika. Beograd: Filološki fakultet Univerziteta u Beogradu.

Живковић 2013: Živković, D. (2013). Uloga stranih jezika u interkulturnom obrazovanju. U: Zbornik radova Jezik, književnost, vrednosti: Jezička istraživanja. Niš: Univerzitet u Nišu. Preuzeto 09. juna 2015., sa http://njnjnj.academia.edu/4158200/Uloga_stranih_jezika_u_ interkulturnom_obrazovanju

Каменов 1999: Kamenov, E. (1999). Predškolska pedagogija. Beograd: Zavod za udžbenike i nastavna sredstva.

Лукач Зоранић и Ивановић (2014): Lukač Zoranić, A., \& Ivanović, A. R. (2014). Interkulturalno obrazovanje: Nužnost današnjice. U: Zbornik radova II Međunarodne konferencije „Bosna i hercegovina i euroatlantske integracije - Trenutni izazovi i perspektive", god. 2, br. 2, tom II, UDK 37-01, str.1081-1999. Bihać: Pravni fakultet Bihać i Centar za društvena istraživanja Internacionalnog Burč Univerziteta.

Порше и др. 1998: Porcher, L., \& Groux, D. (1998). L'apprentissage précoce des langues. Paris: Presses Universitaires de France.

Хлопек 2008: Chlopek, Z. (2008). The Intercultural Approach to EFL Teaching and Learning. Preuzeto 10. oktobra 2015., sa http://americanenglish.state.gov/files/ae/resource_files/08-46-4-c.pdf. 


\section{Jelena Višacki}

\section{L'ÉDUCATION INTERCULTURELLE ET L'APPRENTISSAGE DES LANGUES ÉTRANGÈRE AU NIVEAU PRÉSCOLAIRE}

\section{Résumé}

Suite à l'accroissement du contact interculturel, dû avant tout aux phénomènes contemporains tels que la mondialisation et la migration, le but de l'apprentissage d'une langue étrangère est aujourd'hui orienté avant tout à l'acquisition de la compétence de communication. En effet, pour pouvoir communiquer de manière efficace, il ne suffit plus d'apprendre la langue, il fautaussi connaitre l'identité culturelle de son interlocuteur. C'est pourquoi, l'éducation interculturelle fait désormais partie intégrante de l'enseignement des langues à tous les niveaux. Étant donné que la prise de conscience et la prise en compte de la diversité culturelle influence le développement de la tolérance et d'une attitude ouverte aux diverses valeurs et traditions, aux différentes manières de voir et de penser, l'intégration de l'approche interculturelle s'avère utile dès le plus jeune âge, c'est-à-dire au moment où la construction de la personnalité est encore en cours. En Serbie, le niveau d'ouverture aux étrangers, aux diverses religions et aux différente cultures n'étant pas vraiment satisfaisant, l'introduction de la dimension interculturelle est d'autant plus importante.

L'un des défis majeurs de cette intégration de l'éducation interculturelle dans l'enseignement des langues étrangères aux niveau préscolaire, c'est l'éducation et la formation des enseignants. Ces derniers doivent prendre conscience des avantages que peut procurer la sensibilisation interculturelle des enfants et se libérer de leurs propres préjugés. L'intégration même de l'aspect interculturel au sein du processus d'enseignement ne devrait pas poser de problèmes, les questions et les commentaires des élèves servant le plus souvent d'introduction suffisante aux discussions et aux activités sur le thème de la culture. Toutes ces conclusions sont illustrées à la fin du texte par plusieurs exemples recueillis par observation de cours de langues étrangères dans différents établissements préscolaires de Belgrade.

Mots clés: éducation interculturelle, langue étrangère, âge préscolaire, formation 